\title{
Iron addition as a shallow lake restoration measure: impacts on charophyte growth
}

\author{
Anne K. Immers • Masha T. Van der Sande • \\ Rene M. Van der Zande $\cdot$ Jeroen J. M. Geurts • \\ Ellen Van Donk $\cdot$ Elisabeth S. Bakker
}

Received: 1 July 2011 / Accepted: 30 December 2011/Published online: 24 January 2012

(C) The Author(s) 2012. This article is published with open access at Springerlink.com

\begin{abstract}
Eutrophication has caused a decline of charophyte species in many shallow lakes in Europe. Even though external inputs of phosphorus are declining, internal loading of $\mathrm{P}$ from the sediment seems to delay the recovery of these systems. Iron is a useful chemical binding agent to combat internal phosphorus loading. However, the effects of iron addition on charophytes are not yet known. In this study we experimentally tested the potential toxicity of iron(III)chloride $\left(\mathrm{FeCl}_{3}\right)$ on two different charophytes, Chara virgata Kützing and Chara globularis Thuiller added at the concentration of $20 \mathrm{~g} \mathrm{Fe} \mathrm{m}^{-2}$ and $40 \mathrm{~g} \mathrm{Fe} \mathrm{m}^{-2}$ to the surface water. C. virgata growth was not significantly affected, whereas
\end{abstract}

Guest editors: Zhengwen Liu, Bo-Ping Han \& Ramesh D. Gulati / Conservation, management and restoration of shallow lake ecosystems facing multiple stressors

A. K. Immers $(\square) \cdot$ M. T. Van der Sande .

R. M. Van der Zande - E. Van Donk - E. S. Bakker

Department of Aquatic Ecology, Netherlands Institute of Ecology (NIOO-KNAW), Droevendaalsesteeg 10, 6708 PB Wageningen, The Netherlands

e-mail: a.immers@nioo.knaw.nl

J. J. M. Geurts

Institute for Wetland and Water Research,

Heyendaalseweg 135, 6525 AJ Nijmegen,

The Netherlands

E. Van Donk

Institute of Environmental Biology, Utrecht University,

Padualaan 8, 3584 CH Utrecht, The Netherlands
C. globularis growth significantly decreased with increasing iron concentrations. Nonetheless, biomass of both species increased in all treatments relative to starting conditions. The decrease of $C$. globularis biomass with high iron additions may have been caused by a drop in $\mathrm{pH}$ and alkalinity in combination with iron induced light limitation. Iron addition over a longer time scale, however, will not cause this rapid drop in $\mathrm{pH}$. Therefore, we conclude that adding iron(III)chloride in these amounts to the surface water of a lake can potentially be a useful restoration method.

Keywords Charophyte - Macroalgae - Iron · Phosphate $\cdot$ Shallow lake restoration

\section{Introduction}

Submerged macrophytes play a crucial role in the maintenance of water transparency and aquatic biodiversity in shallow water bodies (Timms \& Moss, 1984; Scheffer et al., 1993). However, macrophyte species seem to differ in the success at which they perform this role (Engelhardt \& Ritchie, 2001). Particularly the group of charophytes (Characeae) has been documented to be more successful in maintaining water clarity than for example Potamogeton species (Hargeby et al., 2007, Ibelings et al., 2007, Bakker 
et al., 2010). Charophytes are green macroalgae, the closest ancestors of land plants (Karol et al., 2001), which are known as species of high conservation value (Lamers et al., 2006) and are commonly found in clear, hard, and nutrient poor water bodies of relatively high alkalinity (Simons \& Nat, 1996; Van den Berg et al., 1998b; Kufel \& Kufel, 2002). Under these conditions, charophytes can improve their own light climate by forming dense beds on the sediment surface (Kufel \& Kufel, 2002; Van Donk \& Van de Bund, 2002), which have a high nutrient uptake, enhance sedimentation and counteract fish or wind induced sediment resuspension (Scheffer et al., 1993; Van den Berg et al., 1998a; Van den Berg et al., 1999; Kufel \& Kufel, 2002). Charophytes may also directly reduce phytoplankton and periphyton growth by releasing allelopathic substances (Mulderij et al., 2003).

High nutrient loading and a subsequent increase in water turbidity due to phytoplankton surface blooms have led to a decrease of charophytes in many shallow lakes in Europe (Van den Berg et al., 1998a, b; Klosowski et al., 2006; Lambert \& Davy, 2010). Recent restoration measures, where external phosphorus $(\mathrm{P})$ input and water turbidity were experimentally reduced, have led to the return of dense charophyte beds (Van den Berg et al., 1998a; Meijer et al., 1999; Ibelings et al., 2007). These restoration measures, however, were performed in sandy lakes, whereas peaty lakes are suffering from high internal loading of $\mathrm{P}$ from the sediment and are more prone to sediment resuspension (Cooke et al., 1993; Jeppesen et al., 1998; Søndergaard et al., 2003). Under natural conditions, peaty lakes in the Netherlands would not suffer from internal $\mathrm{P}$ loading, as upwelling iron rich groundwater binds to phosphorus (in the form of phosphate, $\mathrm{PO}_{4}$ ) in the sediment. This seepage, however, has disappeared over the years due to high regional and local use of groundwater (Smolders \& Roelofs, 1996; Van der Welle et al., 2007). Water managers have tried to resolve this problem by adding iron $(\mathrm{Fe})$, in the form of iron(III)chloride, to the lake sediment as a natural $\mathrm{P}$ binding agent (Cooke et al., 1993; Boers et al., 1994; Burley et al., 2001). In this way, the iron would not only precipitate with the available $\mathrm{P}$ in the sediment, but would also form a barrier on the top layer of the sediment, preventing internal P loading of the lake in the future. However, lake restoration by adding iron in the lake sediment is a costly and time consuming process, therefore adding iron to the surface water may be more feasible in case of restoration of a whole lake. The effect of this iron addition, and the consequential potential drop in $\mathrm{pH}$, on various organisms in the aquatic food web is not yet well studied, whereas it is very important to know whether iron addition may be harmful for the target species that are aimed to return to the restored lake.

Charophytes are desirable species for water managers to grow in a lake as they are indicators of good water quality (Lambert \& Davy, 2010) and have been shown to return in peat lakes after restoration measures had been taken including external nutrient reduction (Rip et al., 1992) and biomanipulation (Ter Heerdt \& Hootsmans, 2007). As charophytes primarily utilize nutrients from the water column instead of the sediment (Kufel \& Kufel, 2002; Hidding et al., 2010), possible effects of iron on charophytes would be more pronounced when adding iron in the water column.

The aim of this study was to test whether iron affects the growth, biomass allocation and nutrient concentration of two different charophyte species. The experiment was based upon the situation of Lake Terra Nova, the Netherlands, in which this method of $\mathrm{FeCl}_{3}$ addition to the surface water is now being applied.

\section{Methods}

\section{Experimental set-up}

Mesocosm experiments were performed in May 2010 in 45 Perspex cylinders $(d \times h=10 \times 50 \mathrm{~cm})$ which were placed in a temperature controlled culture room at the NIOO-KNAW in Nieuwersluis. Temperature was kept constant at $19^{\circ} \mathrm{C}$ and light regime was set at $12 \mathrm{~h}$ light and $12 \mathrm{~h}$ darkness with a light intensity at the water surface of $100 \pm 5 \mu \mathrm{mol}$ photons $\mathrm{m}^{-2} \mathrm{~s}^{-1}$. Each cylinder was filled up with 0.501 peat sediment, collected on April 2010 in Lake Terra Nova $\left(52^{\circ} 12^{\prime} \mathrm{N}\right.$, $5^{\circ} 02^{\prime} \mathrm{E}$, The Netherlands), and subsequently very carefully 3.251 of filtrated $(0.2 \mu \mathrm{m}, \mathrm{ME} 24$, Whatman, Brentford, UK) Terra Nova water was poured on the sediment. To enable pore water sampling, Rhizon soil moisture samplers (Eijkelkamp Agrisearch Equipment, Giesbeek, The Netherlands) attached to $50 \mathrm{ml}$ vacuum syringes were inserted into the upper layer of the sediment. 
During the experiment we manipulated two factors: namely the iron addition and the plants on which the effects of iron addition were tested. The iron and plant treatments consisted each of three levels. The effects of iron addition were tested during 5 weeks, with three different levels of iron which would correspond to additions in Lake Terra Nova of $20 \mathrm{~g} \mathrm{Fe} \mathrm{m}^{-2}$ (low) and $40 \mathrm{~g} \mathrm{Fe} \mathrm{m}^{-2}$ (high) in the form of $\mathrm{FeCl}_{3}$ and a control addition $\left(0 \mathrm{~g} \mathrm{Fe} \mathrm{m}^{-2}\right)$ was designed which received $\mathrm{NaCl}$ in equal molar amounts of chloride in the high iron additions. The plant treatment levels consisted of cylinders filled with $C$. virgata Kützing, Chara globularis Thuiller and empty cylinders. All nine combinations of levels were experimentally tested with five replicates, which were randomized in blocks.

Chara virgata was collected from experimental ponds in Loenderveen $\left(52^{\circ} 12^{\prime} \mathrm{N}, 5^{\circ} 02^{\prime} \mathrm{E}\right.$, The Netherlands) on 29 April 2010. C. globularis was prior to the experiment grown in aquaria from propagules in Terra Nova sediment. A bundle composed of $3 C$. virgata shoots was planted in the sediment of 15 cylinders (total FW per cylinder $0.16 \pm 0.04 \mathrm{~g}$ ), a bundle of 3 C. globularis shoots in 15 other cylinders (total FW per cylinder $0.89 \pm 0.38 \mathrm{~g}$ ), and the last 15 cylinders were not planted with macroalgae as controls.

To distinguish between the effects of iron toxicity and $\mathrm{P}$ limitation we reduced $\mathrm{P}$ in control iron additions at the onset of the experiment with a low dose of $0.33 \mathrm{mg} \mathrm{FeCl}$ per cylinder. During the experiment, iron was added two times every week on 8 addition days, which corresponds to the low and high iron addition of 28.75 and $57.50 \mathrm{mg} \mathrm{FeCl}_{3}$ per addition day, respectively.

\section{Sampling and analysis}

Once every week during the experiment, $35 \mathrm{ml}$ samples of surface water were taken from each cylinder for chemical analyses. A subsample of $10 \mathrm{ml}$ from each cylinder was filtrated over Whatman GF/C $(1.2 \mu \mathrm{m})$ filters and subsequently stored at $-20^{\circ} \mathrm{C}$ before nutrient analysis. The remaining $25 \mathrm{ml}$ subsample was used to measure $\mathrm{pH}$ and alkalinity with a TIM840 titration manager (Radiometer Analytical, Copenhagen, Denmark). Alkalinity was determined by titrating with $0.01 \mathrm{M} \mathrm{HCl}$ down to $\mathrm{pH} 4.2$. The stored $10 \mathrm{ml}$ subsamples were used to colorimetrically determine $\mathrm{PO}_{4}, \mathrm{NH}_{4}$, and $\mathrm{NO}_{3}$ with a QuAAtro CFA flow analyzer (Seal Analytical, Norderstedt, Germany).

During the last sample day, in addition to prior analyses, $50 \mathrm{ml}$ of sediment pore water samples were collected from each cylinder using Rhizon soil moisture samplers. Samples were stored in $50 \mathrm{ml}$ centrifuge tubes at $-20^{\circ} \mathrm{C}$ directly after the pore water had been collected. The same volume of surface water was, prior to storage in $50 \mathrm{ml}$ centrifuge tubes at $-20^{\circ} \mathrm{C}$, filtrated over a $0.45 \mu \mathrm{m}$ membrane filter (ME 25, Whatman, Brentford, UK). Membrane filters that were used were afterward dried for $24 \mathrm{~h}$ at $60^{\circ} \mathrm{C}$ and later stored in $50 \mathrm{ml}$ centrifuge tubes at $-20^{\circ} \mathrm{C}$. Analyses of stored samples were performed using an inductively coupled plasma emission spectrophotometer (ICP; Liberty 2, Varian, Bergen op Zoom, The Netherlands) according to the Dutch NEN-EN-ISO 17294 to estimate dissolved $\mathrm{Fe}, \mathrm{Al}, \mathrm{Ca}$, and $\mathrm{S}$ in surface and pore water. The same method was used to measure precipitated $\mathrm{Fe}$ in the surface water, which was prior to analysis collected by filtration of surface water on $0.45 \mu \mathrm{m}$ membrane filters (ME 25, Whatman, Brentford, UK), that were subsequently treated with $8 \mathrm{ml}$ nitric acid $(2 \mathrm{M})$.

At the end of the experiment, $\pm 3 \mathrm{~cm}$ of shoot material from each cylinder was placed in a plastic cup with $20 \mathrm{ml}$ of demineralized water for periphyton determination following Zimba \& Hopson (1997). Each cup was shaken gently for $1 \mathrm{~min}$ and subsequently shoot material was taken out, dried for $24 \mathrm{~h}$ at $60^{\circ} \mathrm{C}$ and weighed. Demineralized water with periphyton was filtered over a Whatman GF/C $(1.2 \mu \mathrm{m})$ filter, and afterward filters were dried for $24 \mathrm{~h}$ at $60^{\circ} \mathrm{C}$ and weighed. Subsequently all charophytes were harvested and separated in above- and belowground material. All material was dried for $24 \mathrm{~h}$ at $60^{\circ} \mathrm{C}$, dried shoots from periphyton determination were added and subsequently all material was weighed to determine the total above- and belowground dry weight. Total dry weight at the start of the experiment was calculated with a conversion factor, which was acquired from the fresh and dry weight of several subsamples (for $C$. virgata dry weight $=30 \%$ of fresh weight, for $C$. globularis dry weight $=18 \%$ of fresh weight). A homogenized portion of dry charophyte material was used to determine both $\mathrm{C}$ and $\mathrm{N}$ concentrations with a FLASH 2000 Organic Elemental Analyzer (Interscience, Breda, The Netherlands). Charophyte $\mathrm{P}$ concentrations were acquired by incinerating homogenized dry material for $30 \mathrm{~min}$ at 
$500^{\circ} \mathrm{C}$, followed by digestion in $\mathrm{H}_{2} \mathrm{O}_{2}$ (Murphy \& Riley, 1962) before analysis with a QuAAtro CFA flow analyzer.

\section{Statistical analysis}

Statistical analyses were carried out with SPSS 18.0 (SPSS, Chicago, IL, USA). Differences between treatments for plant biomass, shoot:rhizoid ratio and plant nutrient composition were tested with one-way ANOVA's with iron treatment as a fixed factor followed by a Tukey's post hoc test. Differences in chemical variables and periphyton growth were tested with two-way ANOVA's with iron treatment and plant treatment (consisting of the levels C. virgata, C. globularis or empty cylinders) as fixed factors followed by a Tukey's post hoc test. Prior to analysis, all data were tested for normality and homogeneity of variance, and if necessary, data were $\log 10$ transformed. For data that had no normal distribution, even after transformation, a non-parametric KruskalWallis test was used with Statistica 9.1 (StatSoft Inc., Tulsa, OK, USA) to analyze variances. Results were expressed as mean \pm standard error of mean and $P \leq 0.05$ was accepted for statistical significance.

\section{Results}

\section{Charophyte response}

Both charophyte species biomass increased notably over the 5 weeks that the experiment ran. $C$. virgata experienced on average a fourfold increase, from $0.05 \pm 0.00$ to $0.20 \pm 0.02 \mathrm{~g}$ dry weight, whereas C. globularis, which started with a higher mean biomass of $0.15 \pm 0.02 \mathrm{~g}$ dry weight, increased on average threefold to $0.51 \pm 0.04 \mathrm{~g}$ dry weight. Iron additions had different effects on the two species (Fig. 1). C. virgata above ground and below ground biomass were not significantly affected by iron additions (Table 1), although at the highest level of iron addition $C$. virgata biomass tended to be somewhat lower (Fig. 1). The growth of C. globularis, however, was negatively affected by iron additions (Fig. 1). C. globularis below ground material, which only on average made up $6 \%$ of total biomass, did not differ between iron additions, but above ground material was considerably lower in cylinders which

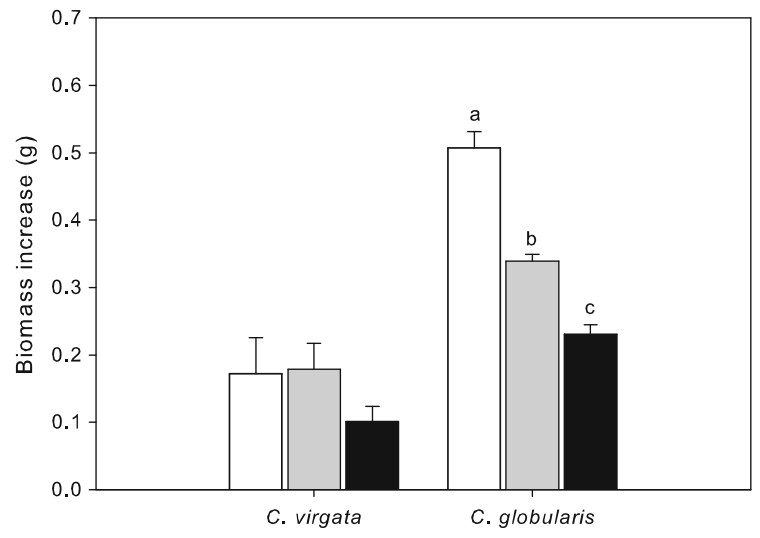

Fig. 1 Biomass increase (average \pm SEM) in reaction to iron addition after 5 weeks for Chara virgata and Chara globularis. White, grey, and black bars represent, respectively, additions of 0,20 , and $40 \mathrm{~g} \mathrm{Fe} \mathrm{m}^{-2}$. Significant differences between iron additions are indicated for each species separately by different letters (Analysis of variance, Tukey test, $P \leq 0.05$ )

received iron compared to cylinders in which no iron was added (Table 1). Total biomass, which was on average composed of $94 \%$ above ground material thus decreased with increasing iron concentrations (Table 1). Biomass allocation of both C. virgata and C. globularis was not affected by iron addition, as charophyte shoot:rhizoid ratio did not differ between iron additions (Table 1).

Tissue nutrient concentrations for $C$. virgata increased significantly during the experiment for $\mathrm{N}$ and $\mathrm{P}$, respectively, from $12.58 \pm 0.35$ to mean end concentrations of $22.27 \pm 1.14 \mathrm{mg} \mathrm{N} \mathrm{g} \mathrm{dry} \mathrm{weight}{ }^{-1}$ and from $1.05 \pm 0.01$ to mean end concentrations of $1.76 \pm 0.06 \mathrm{mg} \mathrm{P}$ g dry weight ${ }^{-1}$. Different iron additions, however, did not induce any differences in $\mathrm{N}$ or $\mathrm{P}$ concentrations and their relative ratios in this charophyte (Table 1). This relationship was not seen in the tissue of $C$. globularis, where the control iron addition $\left(0 \mathrm{~g} \mathrm{Fe} \mathrm{m}^{-2}\right)$ remained similar to the start conditions $\left(1.18 \pm 0.01 \mathrm{mg} \mathrm{P} \mathrm{g}\right.$ dry weight ${ }^{-1}$ and

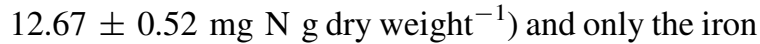
additions of 20 and $40 \mathrm{~g} \mathrm{Fe} \mathrm{m}^{-2}$ induced a significant increase in $\mathrm{N}$ and $\mathrm{P}$ concentrations and their relative ratios (Table 1).

The amount of periphyton, the reddish colored material growing on the charophyte shoots (Fig. 2), was clearly affected by iron additions. For cylinders containing $C$. virgata, the high iron addition (40 $\mathrm{g} \mathrm{Fe} \mathrm{m}^{-2}$ ) yielded significantly more periphyton than the low iron addition $\left(20 \mathrm{~g} \mathrm{Fe} \mathrm{m}^{-2}\right)$. Cylinders 
Table 1 Mean ( \pm sem) end results of charophyte biomass, growth, shoot:rhizoid ratio and nutrient composition of $C$. virgata and C. globularis at different iron additions

\begin{tabular}{|c|c|c|c|c|c|}
\hline & \multicolumn{3}{|l|}{ Mean \pm SEM } & \multicolumn{2}{|c|}{$\begin{array}{l}\text { Effect iron amount } \\
\mathrm{df}=2,14\end{array}$} \\
\hline & $0 \mathrm{~g} \mathrm{Fe} \mathrm{m}^{-2}$ & $20 \mathrm{~g} \mathrm{Fe} \mathrm{m}^{-2}$ & $40 \mathrm{~g} \mathrm{Fe} \mathrm{m}^{-2}$ & $\overline{\mathrm{F}}$ & $P$ \\
\hline \multicolumn{6}{|l|}{ C. virgata } \\
\hline Biomass below ground (g) & $0.03 \pm 0.01$ & $0.03 \pm 0.01$ & $0.02 \pm 0.00$ & 1.49 & 0.26 \\
\hline Biomass above ground (g) & $0.19 \pm 0.04$ & $0.20 \pm 0.04$ & $0.13 \pm 0.02$ & 1.03 & 0.39 \\
\hline Total biomass (g) & $0.22 \pm 0.05$ & $0.23 \pm 0.04$ & $0.15 \pm 0.02$ & 1.13 & 0.36 \\
\hline Total biomass increase $(\mathrm{g})$ & $0.17 \pm 0.05$ & $0.18 \pm 0.04$ & $0.10 \pm 0.02$ & 1.14 & 0.35 \\
\hline Shoot:rhizoid ratio $\left(\mathrm{g} \mathrm{g}^{-1}\right)$ & $0.87 \pm 0.03$ & $0.89 \pm 0.01$ & $0.90 \pm 0.02$ & 0.66 & 0.54 \\
\hline $\mathrm{C}\left(\mathrm{mg} \mathrm{g}\right.$ dryweight $\left.^{-1}\right)$ & $273.90 \pm 14.25$ & $272.51 \pm 2.79$ & $291.96 \pm 10.85$ & 1.07 & 0.37 \\
\hline $\mathrm{N}$ (mg g dryweight ${ }^{-1}$ ) & $20.47 \pm 2.51$ & $21.38 \pm 0.08$ & $24.95 \pm 0.92$ & 2.35 & 0.14 \\
\hline 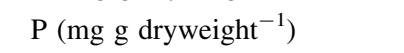 & $1.81 \pm 0.13$ & $1.66 \pm 0.13$ & $1.82 \pm 0.06$ & 0.62 & 0.56 \\
\hline $\mathrm{C}: \mathrm{N}$ ratio $\left(\mathrm{mol} \mathrm{mol}^{-1}\right)$ & $16.14 \pm 1.25$ & $14.87 \pm 0.13$ & $13.68 \pm 0.41$ & 2.60 & 0.12 \\
\hline $\mathrm{N}: \mathrm{P}$ ratio $\left(\mathrm{mol} \mathrm{mol}^{-1}\right)$ & $25.43 \pm 3.06$ & $29.18 \pm 2.32$ & $30.50 \pm 1.64$ & 1.19 & 0.34 \\
\hline Periphyton ( $g$ g dryweight ${ }^{-1}$ ) & $0.38 \pm 0.06^{\mathrm{ab}}$ & $0.21 \pm 0.04^{\mathrm{a}}$ & $0.44 \pm 0.07^{\mathrm{b}}$ & 3.39 & 0.04 \\
\hline \multicolumn{6}{|l|}{ C. globularis } \\
\hline Biomass below ground $(\mathrm{g})$ & $0.03 \pm 0.01$ & $0.02 \pm 0.00$ & $0.02 \pm 0.00$ & 3.07 & 0.08 \\
\hline Biomass above ground (g) & $0.65 \pm 0.05^{\mathrm{a}}$ & $0.44 \pm 0.02^{\mathrm{b}}$ & $0.34 \pm 0.03^{\mathrm{b}}$ & 22.03 & $<0.001$ \\
\hline Total biomass $(\mathrm{g})$ & $0.69 \pm 0.05^{\mathrm{a}}$ & $0.46 \pm 0.02^{\mathrm{b}}$ & $0.39 \pm 0.02^{\mathrm{b}}$ & 21.85 & $<0.001$ \\
\hline Total biomass increase (g) & $0.51 \pm 0.02^{\mathrm{a}}$ & $0.34 \pm 0.01^{\mathrm{b}}$ & $0.23 \pm 0.01^{\mathrm{c}}$ & 66.66 & $<0.001$ \\
\hline Shoot:rhizoid ratio $\left(\mathrm{g} \mathrm{g}^{-1}\right)$ & $0.96 \pm 0.01$ & $0.96 \pm 0.01$ & $0.95 \pm 0.01$ & 0.91 & 0.43 \\
\hline $\mathrm{C}\left(\mathrm{mg}_{\mathrm{g}}\right.$ dryweight $\left.^{-1}\right)$ & $258.12 \pm 5.66$ & $267.11 \pm 4.70$ & $270.17 \pm 15.76$ & 0.42 & 0.67 \\
\hline $\mathrm{N}$ (mg g dryweight ${ }^{-1}$ ) & $14.86 \pm 0.82^{\mathrm{a}}$ & $20.91 \pm 1.20^{\mathrm{b}}$ & $23.12 \pm 1.70^{\mathrm{b}}$ & 10.93 & 0.002 \\
\hline $\mathrm{P}\left(\mathrm{mg} \mathrm{g}\right.$ dryweight $^{-1}$ ) & $1.10 \pm 0.02^{\mathrm{a}}$ & $1.21 \pm 0.01^{\mathrm{b}}$ & $1.46 \pm 0.03^{\mathrm{c}}$ & 67.47 & $<0.001$ \\
\hline $\mathrm{C}: \mathrm{N}$ ratio $\left(\mathrm{mol} \mathrm{mol}^{-1}\right)$ & $20.52 \pm 1.22^{\mathrm{a}}$ & $15.08 \pm 0.83^{\mathrm{b}}$ & $13.70 \pm 0.48^{\mathrm{b}}$ & 14.39 & 0.001 \\
\hline $\mathrm{N}: \mathrm{P}$ ratio $\left(\mathrm{mol} \mathrm{mol}^{-1}\right)$ & $29.89 \pm 1.68^{\mathrm{a}}$ & $38.19 \pm 1.90^{\mathrm{b}}$ & $35.17 \pm 1.80^{\mathrm{ab}}$ & 5.45 & 0.02 \\
\hline Periphyton (g g dryweight ${ }^{-1}$ ) & $0.17 \pm 0.05^{\mathrm{a}}$ & $0.50 \pm 0.08^{\mathrm{ab}}$ & $0.81 \pm 0.18^{\mathrm{b}}$ & 7.63 & 0.01 \\
\hline
\end{tabular}

Data were analyzed with a one-way ANOVA with the levels of iron treatment $\left(0,20\right.$, or $\left.40 \mathrm{~g} \mathrm{~m}^{-2}\right)$ as a fixed factor, $n=5$. Significant differences between iron additions are indicated for each species separately by different letters (analysis of variance, Tukey test, $P \leq 0.05$ ). Bold values indicate $P \leq 0.05$

containing $C$. globularis, on the other hand, showed no difference in periphyton biomass between the iron additions, but the high iron addition had considerably more periphyton biomass than the control iron addition $\left(0 \mathrm{~g} \mathrm{Fe} \mathrm{m}^{-2}\right.$; Table 1$)$.

Moreover, during the experiment a large number of charophyte propagules sprouted from the sediment, which did not seem to be affected by the different iron additions.

\section{Changes in water properties}

Surface water $\mathrm{pH}$ decreased significantly due to iron additions and at the end of the experiment surface water $\mathrm{pH}$ reached mean values of $6.95 \pm 0.17$ in the high iron additions, $7.81 \pm 0.13$ in the low iron additions and mean values of $8.35 \pm 0.22$ in the control additions (Table 2; Fig. 3a). Alkalinity showed the same relationship with low mean values of $0.62 \pm 0.04 \mathrm{mEq} \mathrm{l}^{-1}$ in the high iron additions, $0.95 \pm 0.08 \mathrm{mEq}^{-1}$ for the low iron additions and the highest mean values of $1.55 \pm 0.20 \mathrm{mEq}^{-1}$ in the control additions. Moreover, alkalinity also differed between the charophyte species, with a significant lower alkalinity of $0.62 \pm 0.03 \mathrm{mEq}^{-1}$ in the C. globularis cylinders compared to the empty cylinders or cylinders with $C$. virgata $(1.25 \pm 0.16$ and $1.24 \pm 0.18 \mathrm{mEq} \mathrm{1}^{-1}$; Table 2; Fig. 3b). 

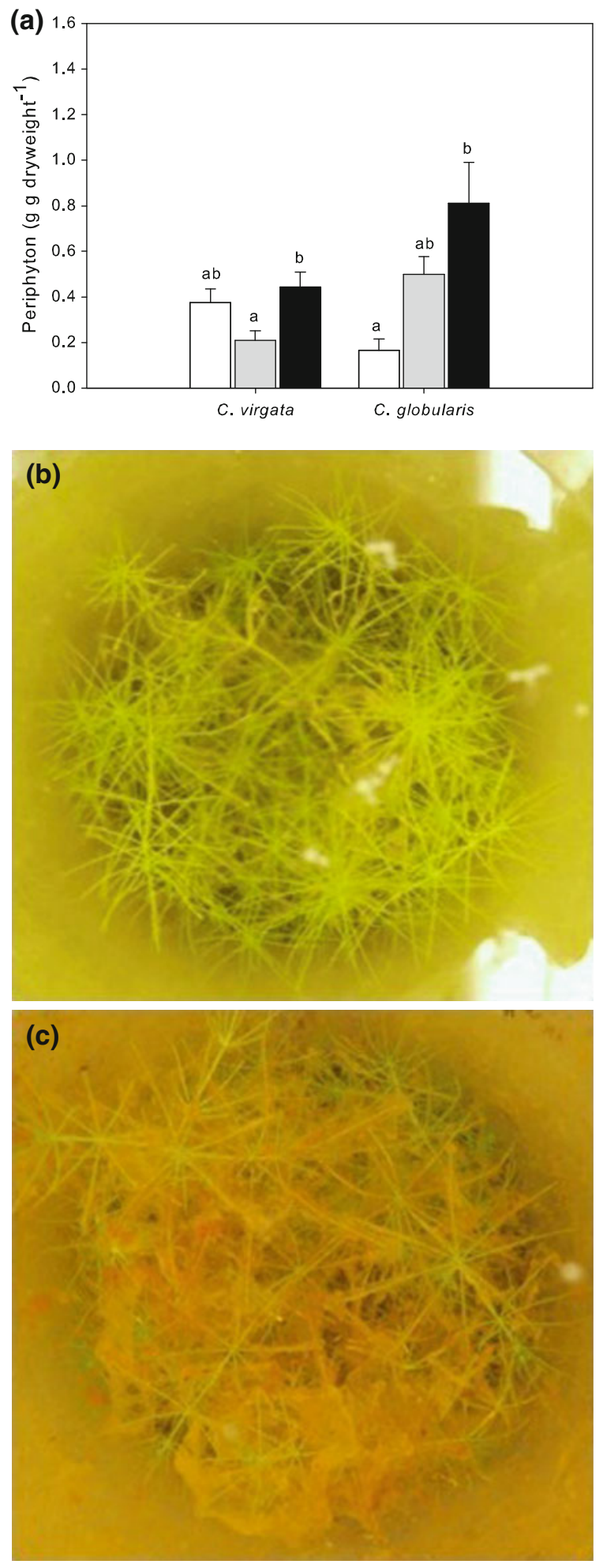

4Fig. 2 a Periphyton material on shoots in $g$ g dry weight ${ }^{-1}$ (average \pm SEM) in reaction to different iron additions. Periphyton may include other material such as precipitated iron. White, grey, and black bars represent, respectively, additions of 0,20 , and $40 \mathrm{~g} \mathrm{Fe} \mathrm{m}^{-2}$. Significant differences between iron additions are indicated for each species separately by different letters (analysis of variance, Tukey test, $P \leq 0.05$ ). Pictures taken at the end of the experiment of Chara globularis receiving, b $0 \mathrm{~g} \mathrm{Fe} \mathrm{m}^{-2}$, and $\mathbf{c} 40 \mathrm{~g} \mathrm{Fe} \mathrm{m}^{-2}$

Iron and aluminum concentrations in the surface water decreased with higher iron additions, however, concentrations in the surface water were very low with mean iron concentrations ranging between $0.37 \pm$ 0.05 and $0.14 \pm 0.04 \mu \mathrm{mol} \mathrm{Fe} 1^{-1}$ and mean aluminum concentrations ranging between $1.93 \pm 0.15$ and $0.21 \pm 0.05 \mu \mathrm{mol} \mathrm{Al} 1^{-1}$. This difference was possibly due to the precipitation of iron with phosphate, however, phosphate concentrations did not differ between iron and control additions, as $\mathrm{P}$ was reduced in the control additions $\left(0 \mathrm{~g} \mathrm{Fe} \mathrm{m}^{-2}\right)$ at the onset of the experiment. Iron and phosphate concentrations in the pore water showed the same ratio with the different iron additions. As a result $\mathrm{Fe}: \mathrm{PO}_{4}$ ratios in sediment, which are often used as a tool to determine internal phosphorus loading, reached mean values of $16.98 \pm$ $4.21 \mathrm{~mol} \mathrm{~mol}^{-1}$, but did not differ significantly between the iron additions. Phosphate also seemed to be lower in the surface water of the cylinders containing $C$. globularis where $\mathrm{P}$ decreased to mean values of $0.05 \pm 0.00 \mu \mathrm{mol} 1^{-1}$ compared to cylinders with $C$. virgata $\left(0.08 \pm 0.01 \mu \mathrm{mol}^{-1}\right)$ and empty cylinders $\left(0.08 \pm 0.01 \mu \mathrm{mol} \mathrm{l^{-1 }}\right)$, however, this difference was not significant (Table 2; Fig. 3c). Precipitated iron, which was measured in the surface water, reached highest values in the cylinders which contained no charophytes (Fig. 3d). No difference was found for precipitated iron between iron additions.

Nitrogen, in the form of $\mathrm{NO}_{3}$ and $\mathrm{NH}_{4}$, decreased significantly during the experiment in the surface water of all cylinders. Nitrate showed a clear significant relationship for the type of charophyte presence in cylinders, with constantly lower values (approaching 0) in cylinders with $C$. globularis compared to higher values in empty cylinders and cylinders with C. virgata (Table 2; Fig. 3e). Ammonium reached highest mean concentrations in cylinders containing 
Table 2 Results of analysis of the effects of iron addition on surface and pore water nutrient composition

\begin{tabular}{|c|c|c|c|c|c|c|}
\hline \multirow[t]{3}{*}{ Effect } & \multirow{2}{*}{\multicolumn{2}{|c|}{$\frac{\text { Iron amount }}{\mathrm{df}=2,36}$}} & \multirow{2}{*}{\multicolumn{2}{|c|}{$\begin{array}{l}\text { Macrophyte species } \\
\mathrm{df}=2,36\end{array}$}} & \multirow{2}{*}{\multicolumn{2}{|c|}{$\frac{\text { Iron } x \text { Macrophyte }}{\mathrm{df}=4,36}$}} \\
\hline & & & & & & \\
\hline & $\mathrm{F} / \mathrm{H}$ & $P$ & $\mathrm{~F} / \mathrm{H}$ & $P$ & $\mathrm{~F} / \mathrm{H}$ & $P$ \\
\hline \multicolumn{7}{|l|}{ Surface water } \\
\hline $\mathrm{pH}^{\mathrm{a}}$ & 18.31 & $<0.001$ & 1.73 & 0.42 & 22.81 & 0.004 \\
\hline Alkalinity $^{\mathrm{a}}$ & 14.45 & $<0.001$ & 14.66 & $<0.001$ & 33.96 & $<0.001$ \\
\hline $\mathrm{Fe}^{\mathrm{a}}$ & 16.64 & $<0.001$ & 1.67 & 0.43 & 19.15 & 0.01 \\
\hline $\mathrm{Fe}(\text { precipitated })^{\mathrm{a}}$ & 1.29 & 0.52 & 6.05 & 0.05 & 11.77 & 0.16 \\
\hline $\mathrm{Al}^{\mathrm{a}}$ & 31.22 & $<0.001$ & 0.28 & 0.87 & 33.10 & $<0.001$ \\
\hline $\mathrm{PO}_{4}$ & 2.86 & 0.07 & 2.80 & 0.07 & 1.63 & 0.19 \\
\hline $\mathrm{NO}_{3}^{\mathrm{a}}$ & 5.71 & 0.06 & 18.48 & $<0.001$ & 28.50 & $<0.001$ \\
\hline $\mathrm{NH}_{4}^{\mathrm{a}}$ & 3.27 & 0.20 & 33.31 & $<0.001$ & 37.50 & $<0.001$ \\
\hline $\mathrm{Ca}^{\mathrm{a}}$ & 5.57 & 0.06 & 2.39 & 0.30 & 13.28 & 0.10 \\
\hline $\mathrm{S}$ & 0.21 & 0.81 & 2.18 & 0.13 & 0.28 & 0.89 \\
\hline \multicolumn{7}{|l|}{ Pore water } \\
\hline $\mathrm{Fe}^{\mathrm{a}}$ & 1.59 & 0.45 & 0.31 & 0.86 & 4.52 & 0.81 \\
\hline $\mathrm{Al}^{\mathrm{a}}$ & 21.55 & $<0.001$ & 0.36 & 0.83 & 25.69 & 0.001 \\
\hline $\mathrm{PO}_{4}^{\mathrm{a}}$ & 0.05 & 0.98 & 10.50 & 0.01 & 12.44 & 0.13 \\
\hline $\mathrm{Fe}: \mathrm{PO}_{4}^{\mathrm{a}}$ & 2.20 & 0.33 & 5.34 & 0.07 & 9.98 & 0.27 \\
\hline $\mathrm{NO}_{3}^{\mathrm{a}}$ & 9.90 & 0.01 & 14.80 & $<0.001$ & 25.80 & 0.001 \\
\hline $\mathrm{NH}_{4}^{\mathrm{a}}$ & 0.37 & 0.83 & 2.10 & 0.35 & 3.96 & 0.86 \\
\hline $\mathrm{Ca}$ & 3.16 & 0.04 & 2.65 & 0.08 & 0.90 & 0.47 \\
\hline $\mathrm{S}$ & 0.04 & 0.96 & 0.26 & 0.77 & 0.95 & 0.49 \\
\hline
\end{tabular}

Data were analyzed with a two-way ANOVA $(F)$ or non-parametric Kruskal-Wallis $(H)$ with the levels of iron treatment $(0,20$, or $40 \mathrm{~g} \mathrm{~m}^{-2}$ ) and the levels of plant treatment (Chara virgata, Chara globularis or empty cylinders) as fixed factors, $n=5$. Bold values indicate $P \leq 0.05$

${ }^{\text {a }}$ Non-parametric Kruskal-Wallis test $(H)$ performed instead of ANOVA $(F)$

C. virgata $\left(107.93 \pm 0.42 \mu \mathrm{mol} 1^{-1}\right)$, which differed significantly from cylinders containing C. globularis $\left(105.48 \pm 0.20 \mu \mathrm{mol} \mathrm{l}^{-1}\right)$ and empty cylinders $(104.33 \pm$ $0.19 \mu \mathrm{mol} 1^{-1}$; Fig. 3f). No significant differences were found between treatments for calcium and sulfur and concentrations remained constant at $962.54 \pm$ 48.42 and $331.48 \pm 12.32 \mu \mathrm{mol} \mathrm{l}^{-1}$ for $\mathrm{Ca}$ and $\mathrm{S}$, respectively. Over all, pore water nutrient concentrations seemed to be less affected by the presence/ absence of charophyte species (Table 2).

\section{Discussion}

The decrease of $C$. globularis biomass with increasing iron concentrations might be related to iron toxicity. Negative effects of iron addition on the growth of macrophytes are usually distinguished in two different kinds, namely direct and indirect (Wheeler et al., 1985). According to Van der Welle et al. (2007), direct effects of iron toxicity can be seen in the physical structure of plants. It can act on the leaves by reducing the size or by the formation of black necrotic spots or complete discoloration of leaves and even die-back of old leaves, or in roots which can blacken, stop growing or lack branching (Van der Welle et al., 2006). Other described unfavorable effects were the formation of iron plaques on roots, which could prevent plant nutrient uptake (Van der Welle et al., 2007). These physical symptoms, indicating direct iron toxicity could not be detected in our experiment with C. virgata and C. globularis. Charophytes differ greatly from vascular macrophytes in having only a rhizoid system, on which they do not rely on for 
(a)
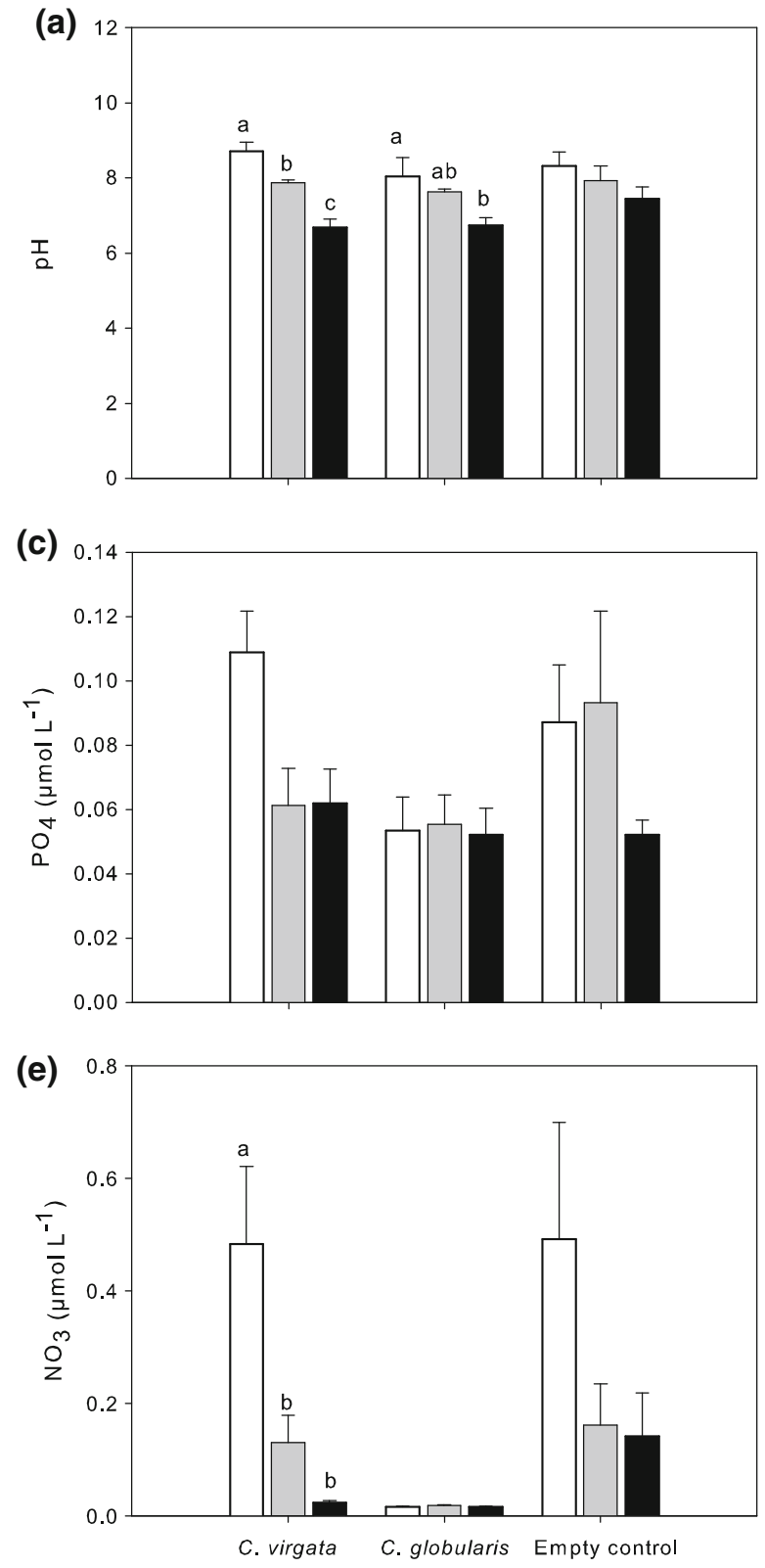

Fig. 3 Surface water (a), $\mathrm{pH}(\mathbf{b})$, alkalinity (c), $\mathrm{PO}_{4}(\mathbf{d})$, precipitated $\mathrm{Fe}(\mathbf{e}), \mathrm{NO}_{3}$, and (f) $\mathrm{NH}_{4}$ concentrations in $\mathrm{mEq}^{-1}$ and $\mu \mathrm{mol} 1^{-1}$ (average \pm SEM) after 5 weeks for the different plant treatment levels under different iron additions. White,

nutrient uptake (Kufel \& Kufel, 2002). These processes of direct iron toxicity as found in vascular macrophytes therefore may not apply for charophytes.

For most higher plant species, iron can have an indirect negative effect on growth by mainly limiting the macronutrient $\mathrm{P}$ due to the precipitation of phosphate with iron (Wheeler et al., 1985). According to
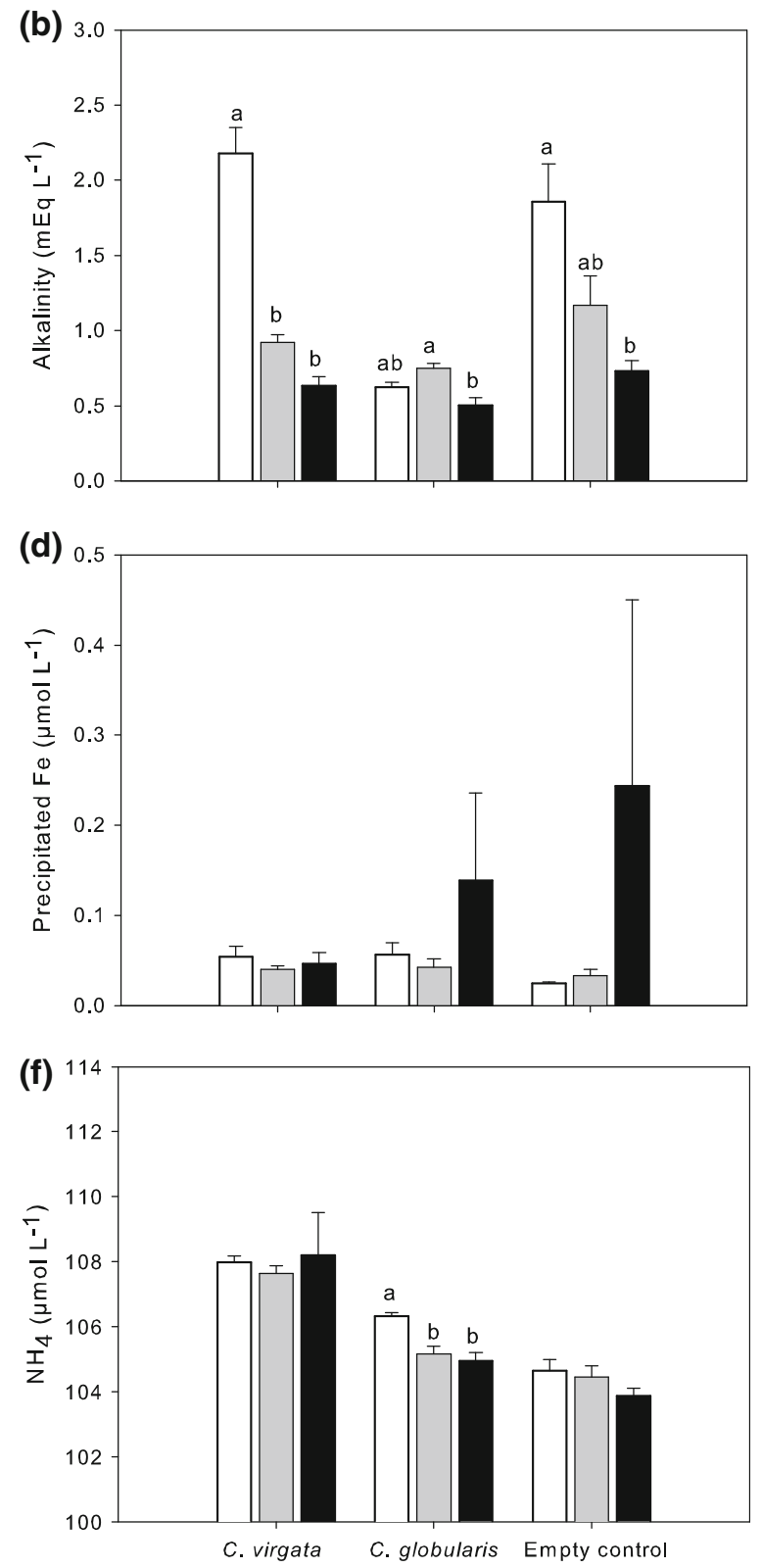

grey, and black bars represent, respectively, cylinders receiving iron additions of 0,20 , and $40 \mathrm{~g} \mathrm{~F} \mathrm{~m}^{-2}$. Significant differences between iron additions are indicated for each species separately by different letters (Kruskal-Wallis, $P \leq 0.05$ )

Koerselman \& Meuleman (1996), macrophytes are P limited at $\mathrm{N}: \mathrm{P}$ ratios measured in plant biomass above 16 and $\mathrm{N}$ limited at N:P ratios below 14. Charophytes, however, are usually only found in lakes with low inorganic P concentrations (Bloemendaal \& Roelofs, 1988; Simons \& Nat, 1996), and are known to give way to higher plants with increasing phosphorus 
concentrations (Kufel \& Kufel, 2002; Lambert \& Davy, 2010). Moreover, for charophyte species, the measured concentrations of the macronutrients $\mathrm{N}$ and $\mathrm{P}$ in plant material not only varies greatly between species, it also differs within species, and usually only gives an indication of the environment in which the charophytes are growing (Kufel \& Kufel, 2002). In our experiment $\mathrm{N}$ and $\mathrm{P}$ concentrations in $C$. globularis increased with increasing iron addition whereas this did not happen in C. virgata, at least not significantly. For both species, the N:P ratio was above 16, suggesting $\mathrm{P}$ limitation if this threshold can be used for Characeae. However, if considering actual concentrations for both $\mathrm{N}$ and $\mathrm{P}$, both species were always above limiting levels of 13 and $1.3 \mathrm{mg} \mathrm{g}$ dryweight $^{-1}$ (Gerloff \& Krombholz, 1966) for N and P respectively, indicating that these plants were not limited by these nutrients. Measurements of water nutrients did not show evidence of increasing P limitation as well, but indicated a strong reduction of nitrate by $C$. globularis relative to $C$. virgata and the cylinders with no plants, whereas there were no differences in phosphate. Most research on charophyte growth limitation has focused on the effects of P, but recently Lambert \& Davy (2010) showed that N, particularly nitrate, may strongly affect growth and abundance of Characeae. The accumulation of $\mathrm{N}$ and $\mathrm{P}$ in the tissue of $C$. globularis in our study may be explained by the reduced growth of this species at higher iron addition, which would simultaneously explain the lack of significant changes in $\mathrm{N}$ and $\mathrm{P}$ concentration in $C$. virgata tissue as this species did not experience a significant growth reduction with iron addition. As less biomass is formed, nutrients may accumulate in plant tissue. Reduced growth can in this case be the result of toxic effects of iron, or the fact that other factors have become limiting.

In addition to nutrients, light can be a limiting factor of plant growth. Another indirect negative effect of iron addition could be the formation of iron precipitates and their shading effect on shoots. No differences were found between iron additions for the presence of precipitated iron; however, precipitated iron was only measured in surface water and not on charophyte shoots, cylinders or on the sediment surface. Most of the iron could have accumulated on these surfaces as ironphosphates or iron oxides. The amount of measured periphyton material on shoots did show a relation with iron concentrations, as highest periphyton biomass for both species in the high iron additions. Whereas the method of shaking plant shoots is commonly applied to quantify periphyton biomass on the plants, other material on the leaves, such as the iron precipitates is included in this measurement. When looking at the color of the periphyton and the difference between periphyton in the high iron and in the control additions, the reddish colored periphyton in iron additions does most probably contain iron precipitates. For charophytes, light is a crucial factor for growth (Kufel \& Kufel, 2002; Rip et al., 2007). Consequently, dense growth of periphyton and iron precipitation could have limited charophyte growth in high iron additions.

The addition of iron also resulted in a decrease in $\mathrm{pH}$ and alkalinity in the cylinders receiving high iron additions. Even though the $\mathrm{pH}$ stayed well within the optimal range of 5-7 for maximal iron phosphate binding capacity (Cooke et al., 1993), the lower pH and alkalinity were suboptimal for the charophytes, as they require a high $\mathrm{pH}$ and high alkalinity of the surface water (Van den Berg et al., 1998b; Klosowski et al., 2006; Lambert \& Davy, 2010). Not only was there a significant difference in alkalinity between the different iron additions, there was also a difference between charophyte species. Cylinders containing C. globularis proved to have a lesser buffer capacity than empty cylinders and cylinders containing C. virgata. This difference might well explain the difference in iron sensitivity, where $C$. globularis was considerably more affected by iron additions than C. virgata. According to Van den Berg et al. (2002), growth of charophytes is strongly correlated to the bicarbonate $\left(\mathrm{HCO}_{3}{ }^{-}\right)$concentrations in the water. The inability of $C$. globularis to maintain the buffer capacity in combination with light limitation could therefore have resulted in decreasing photosynthesis rates and a steady drop in $\mathrm{pH}$ in cylinders of the iron additions due to the quick addition of iron.

Iron as a measure to control eutrophication

The goal of adding Fe to the surface water of lakes is to lower surface water $\mathrm{P}$ and to control internal $\mathrm{P}$ release. The binding capacity of $\mathrm{Fe}$, however, is regulated by the redox state of the agent (Burley et al., 2001). Under oxic conditions, oxidized ferric iron $\left(\mathrm{Fe}^{3+}\right)$ can freely precipitate with $\mathrm{PO}_{4}$, but under anoxic conditions, reduced ferrous iron $\left(\mathrm{Fe}^{2+}\right)$ is formed and $\mathrm{Fe}$ loses this binding capacity and consequently $\mathrm{PO}_{4}$ will be released (Cooke et al., 1993). Charophytes are able 
to oxidize the sediment, thereby preventing this redoxreaction to occur (Kufel \& Kufel, 2002). Moreover, the possibility for charophytes to use bicarbonate as a carbon source for photosynthesis leads to the formation of carbonate, which in turn can precipitate with calcium to form calcite (Otsuki \& Wetzel, 1972). Calcite can subsequently co-precipitate with phosphate, which is a redox-insensitive reaction (Otsuki \& Wetzel, 1972). Charophytes can thus enhance the binding capacity of iron.

The negative effects of the addition of $40 \mathrm{~g} \mathrm{Fe} \mathrm{m}^{-2}$ on C. globularis biomass may have partly been due to the fact that iron was added over a short period of 5 weeks. When using iron addition as a lake restoration measure, the choice can be made for addition distributed over a longer time period. Moreover, a drop in $\mathrm{pH}$ and alkalinity as observed in this experiment will probably not occur in a lake such as Terra Nova with the same amount of iron, as the water column above the sediment is much larger, and therefore negative consequences of iron addition such as a drop in $\mathrm{pH}$ and alkalinity would be much less dramatic (Boers et al., 1994).

From the fact that both species reacted differently on iron addition it might follow that after iron addition, lakes would become dominated by more iron tolerant species, which could possibly cause a shift in community composition. However, the fact that the addition of iron to a fresh water ecosystem will reduce the phosphate concentration in the water and sediment by forming a Fe-trapping barrier on the sediment-water interface will be favorable to push the equilibrium towards a clear, charophyte-dominated ecosystem. And as charophyte establishment was not hampered by the iron layer on the sediment, dense charophyte beds can provide a positive feedback loop resulting in a resilient, clear water state.

Acknowledgments The authors would like to thank Thijs de Boer, Koos Swart, and Martijn Dorenbosch for their practical assistance in the field and Nico Helmsing and Harry Korthals for performing multiple chemical analyses in the lab. This study was funded by the Water Framework Directive Innovation Fund from Agentschap NL from the Dutch Ministry of Economic Affairs, Agriculture and Innovation.

Open Access This article is distributed under the terms of the Creative Commons Attribution Noncommercial License which permits any noncommercial use, distribution, and reproduction in any medium, provided the original author(s) and source are credited.

\section{References}

Bakker, E. S., E. Van Donk, S. A. J. Declerck, N. R. Helmsing, B. Hidding \& B. A. Nolet, 2010. Effect of macrophyte community composition and nutrient enrichment on plant biomass and algal blooms. Basic and Applied Ecology 11: $432-439$.

Bloemendaal, F. H. J. L. \& J. G. M. Roelofs, 1988. Waterplanten en waterkwaliteit. Koninklijke Nederlandse NatuurhistorischeVereniging, Utrecht, The Netherlands (in Dutch).

Boers, P., J. Van der Does, M. Quaak \& J. Van der Vlucht, 1994. Phosphorus fixation with iron(III)chloride: a new method to combat phosphorus loading in shallow lakes? Archiv für Hydrobiologie 129: 339-351.

Burley, K. L., E. E. Prepas \& P. A. Chambers, 2001. Phosphorus release from sediments in hardwater eutrophic lakes: the effects of redox-sensitive and -insensitive chemical treatments. Freshwater Biology 46: 1061-1074.

Cooke, G. D., E. B. Welch, A. B. Martin, D. G. Fulmer, J. B. Hyde \& G. D. Schrieve, 1993. Effectiveness of Al, Ca, and $\mathrm{Fe}$ salts for control of internal phosphorus loading in shallow deep lakes. Hydrobiologia 253: 323-335.

Engelhardt, K. A. M. \& M. E. Ritchie, 2001. Effects of macrophyte species richness on wetland ecosystem functioning and services. Nature 411: 687-689.

Gerloff, G. C. \& P. H. Krombholz, 1966. Tissue analysis as a measure of nutrient availability for the growth of angiosperm aquatic plants. Limnology and Oceanography 11: 529-537.

Hargeby, A., I. Blindow \& G. Andersson, 2007. Long-term patterns of shifts between clear and turbid states in Lake Krankesjön and Lake Tåkern. Ecosystems 10: 28-35.

Hidding, B., R. J. Brederveld \& B. A. Nolet, 2010. How a bottom-dweller beats the canopy: inhibition of an aquatic weed (Potamogeton pectinatus) by macroalgae (Chara spp.). Freshwat. Biol. 55: 1758-1768.

Ibelings, B. W., R. Portielje, E. H. R. R. Lammens, R. Noordhuis, M. S. Van den Berg, W. Joosse \& M.-L. Meijer, 2007. Resilience of alternative stable states during recovery of shallow lakes from eutrophication: Lake Veluwe as a case study. Ecosystems 10: 4-16.

Jeppesen, E., T. L. Lauridsen, T. Kairesalo \& M. R. Perrow, 1998.Impact of submerged macrophytes on fish-zooplankton interactions in lakes. In Jeppesen, E., M. Søndergaard, M. Søndergaard \& K. Christoffersen (eds), The Structuring Role of Submerged Macrophytes in Lakes. Ecological Studies. Springer Verlag, New York 131: 91-114.

Karol, K. G., R. M. McCourt, M. T. Cimino \& C. F. Delwiche, 2001. The closest living relatives of land plants. Science 294: 2351-2353.

Klosowski, S., G. H. Tomaszewicz \& H. Tomaszewicz, 2006. The expansion and decline of charophyte communities in lakes within the Sejny Lake District (north-eastern Poland) and changes in water chemistry. Limnologica 36: 230-240.

Koerselman, W. \& A. F. M. Meuleman, 1996. The vegetation $\mathrm{N}: \mathrm{P}$ ratio: a new tool to detect the nature of nutrient limitation. Journal of Applied Ecology 33: 1441-1450.

Kufel, L. \& I. Kufel, 2002. Chara beds acting as nutrient sinks in shallow lakes-a review. Aquatic Botany 72: 249-260. 
Lambert, S. J. \& A. J. Davy, 2010. Water quality as a threat to aquatic plants: discriminating between the effects of nitrate, phosphate, boron and heavy metals on charophytes. New Phytologist 189: 1051-1059.

Lamers, L. P. M., J. J. M. Geurts, B. Bontes, J. M. Sarneel, H. W. Pijnappel, H. Boonstra, J. M. Schouwenaars, M. Klinge, J. T. A. Verhoeven, B. W. Ibelings, W. C. E. P. Verberk, B. Kuijper, H. Esselink \& J. G. M. Roelofs, 2006. Onderzoek ten behoeve van het herstel en beheer van Nederlandse laagveenwateren. Eindrapportage 2003-2006. Ede: Netherlands Ministry of Agriculture, Nature and Food Quality: 286 pp (in Dutch).

Meijer, M.-L., I. De Boois, M. Scheffer, R. Portielje \& H. Hosper, 1999. Biomanipulation in shallow lakes in The Netherlands: an evaluation of 18 case studies. Hydrobiologia 408(409): 13-30.

Mulderij, G. E., E. Van Donk \& J. G. M. Roelofs, 2003. Differential sensitivity of green algae to allelopathic substances from Chara. Hydrobiologia 491: 261-271.

Murphy, J. \& J. P. Riley, 1962. A modified single solution method for determination of phosphate in natural waters. Analytica Chimica Acta 26: 31-36.

Otsuki, A. \& G. R. Wetzel, 1972. Coprecipitation of phosphate with carbonates in a marl-lake. Limnology and Oceanography 17: 763-767.

Rip, W. J., K. Everards \& A. Houwers, 1992. Restoration of Botshol (The Netherlands) by reduction of external nutrient load: the effects on physico-chemical conditions, plankton and sessile diatoms. Aquatic Ecology 25: 275-286.

Rip, W. J., Ouboter, M. R. L. \& H. J. Los, 2007. Impact of climatic fluctuations on Characeae biomass in a shallow, restored lake in The Netherlands. Hydrobiologia 584: 415-424.

Scheffer, M., S. H. Hosper, M.-L. Meijer, B. Moss \& E. Jeppesen, 1993. Alternative equilibria in shallow lakes. Trends in Ecology \& Evolution 8: 275-279.

Simons, J. \& E. Nat, 1996. Past and present distribution of stoneworts (Characeae) in The Netherlands. Hydrobiologia 340: $127-135$.

Smolders, A. J. P. \& J. G. M. Roelofs, 1996. The roles of internal iron hydroxide precipitation, sulphide toxicity and oxidizing ability in the survival of Stratiotes aloides roots at different iron concentrations in sediment pore water. New Phytologist 133: 253-260.

Søndergaard, M., J. P. Jensen \& E. Jeppesen, 2003. Role of sediment and internal loading of phosphorus in shallow lakes. Hydrobiologia 506(509): 135-145.
Timms, R. M. \& B. Moss, 1984. Prevention of growth of potentially dense phytoplankton populations by zooplankton grazing in the presence of zooplanktivorous fish in a shallow wetland ecosystem. Limnology and Oceanography 29: 472-486.

Ter Heerdt, G. \& M. Hootsmans, 2007. Why biomanipulation can be effective in peaty lakes. Hydrobiologia 584: 305-316.

Van den Berg, M. S., H. Coops, M.-L. Meijer, M. Scheffer \& J. Simons, 1998a. Clear water associated with a dense Chara vegetation in the shallow and turbid Lake Veluwemeer, The Netherlands. In Jeppesen, E., M. Søndergaard, M. Søndergaard \& K. Christoffersen (eds), The Structuring Role of Submerged Macrophytes in Lakes. Ecological Studies, Vol. 131. Springer Verlag, New York: 339-352.

Van den Berg, M. S., M. Scheffer, H. Coops \& J. Simons, 1998 b. The role of Characean algae in the management of eutrophic shallow lakes. Journal of Phycology 34: 750-756.

Van den Berg, M. S., M. Scheffer, E. Van Nes \& H. Coops, 1999. Dynamics and stability of Chara sp. and Potamogeton pectinatus in a shallow lake changing in eutrophication level. Hydrobiologia 408(409): 335-342.

Van den Berg, M. S., H. Coops, J. Simons \& J. Pilon, 2002. A comparative study of the use of inorganic carbon resources by Chara aspera and Potamogeton pectinatus. Aquatic Botany 72: 219-233.

Van Donk, E. \& W. J. Van de Bund, 2002. Impact of submerged macrophytes including charophytes on phyto- and zooplankton communities: allelopathy versus other mechanisms. Aquatic Botany 72: 261-274.

Van der Welle, M. E. W., M. Cuppens, L. P. M. Lamers \& J. G. M. Roelofs, 2006. Detoxifying toxicants: interactions between sulphide and iron toxicity in freshwater wetlands. Environmental Toxicology and Chemistry 25: 1592-1597.

Van der Welle, M. E. W., A. J. P. Smolders, H. J. M. Op den Camp, J. G. M. Roelofs \& L. P. M. Lamers, 2007. Biogeochemical interactions between iron and sulphate in freshwater wetlands and their implications for interspecific competition between aquatic macrophytes. Freshwater Biology 52: 434-447.

Wheeler, B. D., M. M. Al-Farraj \& R. E. D. Cook, 1985. Iron toxicity to plants in base-rich wetlands: comparative effects on the distribution and growth of Epilobium hirsitum L. and Juncus subnodulosus Schrank. New Phytologist 100: 653-669.

Zimba, P. V. \& M. S. Hopson, 1997. Quantification of epiphyte removal efficiency from submersed aquatic plants. Aquatic Botany 58: 173-179. 